NBER WORKING PAPER SERIES

\title{
IS LOCAL PUBLIC SECTOR RENT EXTRACTION HIGHER IN PROGRESSIVE CITIES OR HIGH AMENITY CITIES?
}

\author{
Matthew E. Kahn \\ Working Paper 23201 \\ http://www.nber.org/papers/w23201 \\ NATIONAL BUREAU OF ECONOMIC RESEARCH \\ 1050 Massachusetts Avenue \\ Cambridge, MA 02138 \\ February 2017
}

I thank Brian Casey, Dora Costa, Ed Glaeser, Nolan Jones and Joe Tracy for useful comments and Joe Nation for sharing his California Pension Tracker database. The views expressed herein are those of the author and do not necessarily reflect the views of the National Bureau of Economic Research.

NBER working papers are circulated for discussion and comment purposes. They have not been peer-reviewed or been subject to the review by the NBER Board of Directors that accompanies official NBER publications.

(C) 2017 by Matthew E. Kahn. All rights reserved. Short sections of text, not to exceed two paragraphs, may be quoted without explicit permission provided that full credit, including () notice, is given to the source. 
Is Local Public Sector Rent Extraction Higher in Progressive Cities or High Amenity Cities?

Matthew E. Kahn

NBER Working Paper No. 23201

February 2017

JEL No. H50,H7,H75,R23

\title{
$\underline{\text { ABSTRACT }}$
}

Public finance theories of the median voter's preferences and local public sector rent extraction posit that liberal cities and high amenity cities will feature a larger, better paid local public sector. Compensating differentials theory predicts that real wages will be lower in beautiful states and localities. Using both Federal and California city level administrative micro data, I study public sector compensation across space. At the Federal level, California workers are only paid 9\% more than observationally identical workers in Alabama. Given the high California home prices, such workers are paying for the California amenities. Within California, beach cities hire more workers but pay them less in real terms. Liberal cities both pay public sector workers more and employ more of them. Liberal cities have much larger per-capita pension liabilities.

\author{
Matthew E. Kahn \\ Department of Economics \\ University of Southern California \\ KAP \\ Los Angeles, CA 90089 \\ and NBER \\ kahnme@usc.edu
}




\section{Introduction}

Research in local public finance posits that the public sector will be larger and its compensation will be more generous in locations featuring unique exogenous amenities because the rich inelastically demand to live in such areas (Brueckner and Neumark 2014). California's beach cities offer a test of this hypothesis. In beach communities ranging from Malibu to Santa Cruz, there are unique exogenous tied attributes that cannot be found inland or in other states. Beach cities also feature significant supply side development constraints. The California's Coastal Commission imposes stringent housing supply limits on new construction close to the beach (Kahn, Vaughn and Zasslof 2010). The combination of inelastic demand for housing and inelastic supply of housing leads to very high home prices and a large per-capita tax revenue base that can be used to fund the public sector (Gyourko, Mayer and Sinai 2009, Saiz 2009, Diamond 2017). Zillow housing data indicates that the average beach city's home features a sales price that is $60 \%$ higher than the price for homes in non-beach cities in the same county.

Another strand of the local public finance literature has argued that progressive cities will create more public sector jobs and offer higher public sector pay because such jobs are a type of redistribution (Alesina and Easterly 1998, Glaeser and Kahn 1999). Progressive cities such as Berkeley and Santa Monica are well known for supporting policies that redistribute income. Residents in these areas support greater redistribution (Luttmer 2001). During a time of rising income inequality, the public sector plays an increasingly important role in providing middle class jobs.

This paper uses two administrative data sets (that are not top coded or self reported) to study the geographic variation in federal and California employee salaries as a function of location specific amenities and local voter preferences for redistribution. I estimate a basic 
Mincer wage regression using repeat cross-sections of the federal employee data. Nominal wages for federal public sector workers are only $9 \%$ higher for California workers than Alabama workers.

Using administrative data for all California city public employees over the years 2009 to 2015, I study both the salaries, benefits and the count of public sector jobs by California City. My data set includes 432 cities. This sample includes 49 beach cities. I find that California's beach cities feature $32 \%$ higher public employment than observationally identical cities in the same county in the same year. Public sector earnings are higher in more liberal cities in California. This is evidence in favor of the taste for local redistribution hypothesis. Within California, there is no statistically significant difference in the nominal wages of beach city workers relative to other public sector workers who work in a non-beach city in the same county in the same year.

Deflating by local real estate prices, I find that beach city public sector workers are paid a lower salary than non-beach city public sector workers who work in the same county. Together, the Federal public sector pay findings for California and the local California findings suggest that public sector workers in the most beautiful locations pay for amenities on the job because they are not being paid a wage premium. These public sector worker findings mirror earlier crossU.S work studying the compensating differentials for private sector workers. Similar to the earlier work of Blomquist, Berger and Hohn (1988) and Gyourko and Tracy (1991), I find that public sector workers earn lower real wages in more desirable areas. Such public sector workers pay for the spatially tied amenities that they consume (Rosen 2002).

Given that California's public sector workers receive a defined benefit retirement funds, public sector pay is likely to translate into larger long term obligations to retired workers. In the 
final section of the paper, I study how California City actuarial and market pension liabilities vary across space. I document that beach cities do not have larger liabilities while liberal cities do have larger per-capita liabilities.

\section{Spatial Compensating Differentials for Federal Public Sector Workers}

To begin to study public sector worker earnings across space, I examine the earnings of federal executive branch workers across U.S states. Given that California is widely viewed as offering the best quality of life in the United States, I test whether federal workers employed in California earn similar salaries as observationally identical federal workers who work in other states. I use Federal data from 1998 to 2014. The Federal Government has created a micro data set that includes all Executive Branch employees (https://www.opm.gov/data/). ${ }^{1}$

In previous work, Brueckner and Neumark (2014) use the CPS to compare quality adjusted workers who work in the public and private sector. In contrast throughout this paper, I will be comparing the earnings and benefits of public sector workers. In this section, I focus on cross-state variation in public sector pay for federal workers in the executive branch. I do not model the decision to work for the federal government. Instead, I simply focus on comparing the earnings of different federal workers who work in different states.

Observed public sector earnings represent an equilibrium determined both by the demand by the federal and local government for workers and the willingness of workers to work at a given salary and the bargaining strength of the union representing the workers. At the Federal level, public sector unions do not negotiate pay (Gyourko and Tracy 1986). Such unions instead can lobby through the political process to raise worker pay. The Bureau of Labor Statistics

\footnotetext{
${ }^{1}$ https://www.opm.gov/policy-data-oversight/data-analysis-documentation/data-policyguidance/hr-reporting/ghrr07_ch1.pdf
} 
makes recommendations to keep federal pay competitive with private sector pay to minimize public to private job transitions (Gyourko and Tracy 1986).

I use the federal pay data to explore spatial compensating differentials in a setting where public sector unions are not powerful. I estimate repeat cross-section public sector Mincer earnings regressions. This approach builds on the work by Blomquist, Berger and Hoem (1988) and Gyourko and Tracy (1991) but rather than taking a parametric stand on what are the key local public goods (such as climate, crime and pollution), I simply include a state fixed effect for each state where Alabama is the omitted category. Define worker $i$ in state 1 at time $t$. I estimate:

$\log \left(\right.$ earnings $\left.s_{i l t}\right)=\gamma_{m t}+B_{t} * X_{i l t}+U_{i l t}$

In the regressions reported in Table One, I control for the occupation of the worker, gender, sixteen government ranks, ethnicity and focus on the state fixed effects. The first finding is the very high $\mathrm{R} 2$ in each cross-sectional regression. The $\mathrm{R} 2$ is never lower than .95 . $^{2}$ The second result is the very small male earnings premium across the years. The third finding is the tiny cross-state earnings differentials. The California coefficient represents the difference between a standardized Federal worker in Alabama and California. In 1998, the quality adjusted Federal worker in California earns 3\% more than his Alabama counterpart. By 2014, this differential has grown to $9 \%$. Based on recent Zillow data, the median value of a single family home in Alabama is $\$ 122,000$ while the median value of a home in California is $\$ 479,000$. This enormous differential indicates that Federal workers are paying to live and work in

\footnotetext{
${ }^{2}$ The federal data includes 444 occupations. When I rerun the regression while dropping the state fixed effects the R2 barely changes.
} 
California. Looking at the other fixed effects no others stand out as large in size. New Jersey has the largest state fixed effect at $11.3 \%$ in 2010 but even this is small in economic terms. California is widely viewed to have the best quality of life in the nation. These results indicate that the Federal workers who work in California are implicitly paying to work there.

\section{California Public Sector Worker Earnings and Benefits Data}

In this section, I present new results based on earnings regressions of California city public sector workers. Throughout this section, I am assuming that city public sector workers who work in a given county in a given year are perfect substitutes with respect to their skill. If workers differ with respect to their skill and if the highest quality workers choose to work in the most beautiful locations, then this would induced a positive correlation such that we should find that public sector workers who work in beach cities earn a wage premium. In the regressions I report below, I will be controlling for city size. If workers are of equal quality, then any observed earnings difference between workers in different cities in the same county is either due to amenity variation or local union bargaining power.

I use data for California city workers over the years 2009 to $2015 .^{3}$ The data provides information on each worker's overall salary, total overtime pay and total benefits and the employer's city or county and type of work but no other attributes of the worker. In the year 2015, the data report the earnings for 314,565 California city workers. The median worker's earnings was $\$ 59,038$ and the mean was $\$ 64,009$. This data set excludes workers in the public education sector.

\footnotetext{
${ }^{3}$ http://publicpay.ca.gov/Reports/RawExport.aspx
} 
To measure local home prices, I use Zillow's city level Median Home Value Index data from June of each year. ${ }^{4}$ To measure each California city's political attributes, I use data from the UC Berkeley IGS for 2012 political party registration. My Liberal vote share is defined as the share of registered voters who are registered as Democrats + Peace and Freedom + Green Party. I also have collected data on each California City's population in 2010.

My final data set includes 417 California cities and 49 of them are beach cities. There are beaches such as Venice Beach that are not an incorporated city. The beach cities are listed in Table 2. Consider Los Angeles County. It features eight beach cities and 80 non-beach cities. I will exploit this within county variation to test for the role of beaches and progressive voter shares.

In Table Three, I use year 2000 census tract data and I run demographic regressions to compare the average demographics in beach cities relative to other cities in the same county. There is no statistically significant differential in poverty rates or population density between beach cities and non-beach cities in the same California County. The results in column (4) show that the Hispanic share is 12.5 percentage points lower in beach cities and the college graduate share is 10.9 percentage points higher in beach cities relative to non-beach cities in the same county. Beach cities also feature higher median incomes and much higher median home prices (see columns 6 and 7).

In Table Four, I further explore the differences in beach cities and non-beach cities in the same California County by using the Zillow median home price index as the dependent variable. Controlling for city population, the average beach city features home prices that are $62 \%$ higher

\footnotetext{
${ }^{4}$ http://www.zillow.com/research/data/
} 
$(\exp (.483)-1)$ than the average non-beach city in the same county. This is strong evidence of the claim that beach cities have unique amenities. As shown in column (2) these cities do not differentially attract progressive voters. The progressive voter share is higher in bigger cities.

\section{California Public Sector Employment, Earnings and Pension Benefits}

In this section, I will study the public sector's employment and pay in beach cities and in more progressive cities. My starting point is to explore the size of the public sector. In the right two columns of Table Four, I report two regressions where the unit of analysis is a city/year. Controlling for county/year fixed effects and a city's population, I find that the public sector's count of employees is $23 \%$ higher in beach cities relative to observationally identical cities in the same county. Zax (1998) offers a possible explanation. He argues that public sector unions seek to improve work conditions for workers by requiring them to work fewer hours and this creates the possibility that in areas where public sector unions have more clout that more workers will be hired to complete the same set of tasks. As shown in column (3), liberal cities also have a larger public sector. A ten percentage point increase in the share of liberal registered voters is associated with a 10.6 percentage point increase in the size of the public sector. Cities with higher home prices also have a larger local government. The elasticity with respect to the Zillow home price index is .45. Column (4) in Table Four repeats this exercise but this time the dependent variable the log of part time workers. I define part time workers as those who earn less than $\$ 15,000$ a year. In this case the beach coefficient grows to $29 \%$.

I study how California city public sector pay varies across cities in the same county. A standard compensating differentials theory would predict that earnings will be lower in high 
amenity areas because working in such a city offers access to great amenities. In contrast, the Brueckner and Neumark (2014) theory of rent extraction would posit that earnings for public sector workers will be higher there. ${ }^{5}$

To study this, I will present two sets of results. In both sets of results set, the unit of analysis is a person $i$ in city 1 in county $m$ in year $t$.

$\log \left(\right.$ earnings $\left._{i l m t}\right)=\gamma_{m t}+B_{1} *$ Liberal $_{l m, 2010}+B_{2} *$ Beach $_{l m t}+B_{3} * \log \left(\right.$ Pop $\left._{l m, 2010}\right)+$ $B_{4} * \log \left(\right.$ Zillow $\left._{\text {lmt }}\right)+U_{\text {ilmt }}$

In this equation (2), the dependent variable is the log of nominal earnings. It is important to note that I include county/year fixed effects in all of the California regressions reported in this paper. In addition to presenting estimates of equation (2), I also present estimates of equation (3).

$\log \left(\frac{\text { earnings }_{\text {limt }}}{\text { Zillow }_{\text {lmt }}}\right)=\gamma_{m t}+B_{1} *$ Liberal $_{l m, 2010}+B_{2} *$ Beach $_{l m t}+B_{3} * \log \left(\right.$ Pop $\left._{l m, 2010}\right)+U_{\text {ilmt }}$

The difference between equation (2) and equation (3) is that in equation (3), I deflate a worker's earnings by the Zillow rental index for that city in that year. The dependent variable in equation (3) allows me to follow Moretti (2014) and to study real wage variation within California counties. More specifically, Zillow reports the single family home median price for a California city in each year (this is measured in nominal dollars). I convert this into a rental expenditure by multiplying it by .075 . The dependent variable in equation (3) can be thought of

\footnotetext{
${ }^{5}$ I know of no publicly available micro data on private sector workers that is geocoded so that one's city of work could be identified (i.e a worker works in the City of Santa Monica or the City of Beverly Hills) that would allow for a private sector earnings regression to be estimated with such fine geographic identifiers.
} 
as the log of a worker's real pay. I report estimates of equation (2) and (3) because I recognize that a worker does not have to live and work in the same jurisdiction but that the spatial correlation of home prices across space means that the worker will have a longer commute if she chooses to work in a high amenity beach city but to live far from that area.

In equations (2) and (3), I include additional explanatory variables such as county by year fixed effects, the city's liberal voter share and population as of the year 2000, a dummy indicating whether the worker works in a beach city and the log of the city's annual Zillow home price index. ${ }^{6}$ The standard errors are clustered by city. The beach indicator controls for within county variation in amenities. The beach cities will feature a lower summer temperature and offer greater beauty and beach access. I include the home price measure because it proxies for the city's income and public sector unions are likely to demand cost of living adjustments to allow workers to earn salaries so that they can afford housing within the jurisdiction. ${ }^{7}$ The city's population controls for urban scale effects and may proxy for the complexity of jobs. A larger county may have the need for higher quality public sector workers.

\footnotetext{
${ }^{6}$ I recognize that a weakness of my approach is that I do not have demographic controls at either the individual level or at the city/year level. While the Census Micro Data do provide place of work PUMAS, these geographic areas are larger than the cities. This means that there is not a one to one mapping from place of work identifiers to California cities. I know of no micro data set that provides the demographic attributes of public sector workers that includes geographic identifiers such as that the worker works in the city of Santa Monica. The census provides more geographically refined data on place of residence but in this study I am focusing on place of work.

${ }^{7}$ Using data for Los Angeles County, Orange County and Ventura provided by Saiz (2009), I have calculated each city's share of mountain land. Saiz (2009) argues that housing supply is more inelastic in these mountainy areas because of the extra construction costs. Diamond (2017) argues that such inelastic supply enables public sector unions to extract more rents. For the subset of 96 cities for which I am able to estimate equation (2) using this additional mountain share variable I find no evidence that all else equal that public sector workers earn higher pay in cities with a greater mountain share.
} 
A weakness of the California administrative data that I discuss below is that it does not have micro human capital controls for age, education, or gender of the workers. In results I report below, I will stratify by specific function and occupation of the workers. If workers differ with respect to skill and if the most skilled self select to work in the beautiful beach cities then this should induce an upward bias on the beach coefficient (for a similar logic in the case of estimating the value of life using hedonic methods see Hwang and Reed 1992).

Table Five reports six estimates of equation (2). Controlling for county/year fixed effects, I estimate a city population elasticity of .22 on annual earnings. As shown across the six regressions, the beach coefficient is never statistically significant. In column (2), I include each city centroid's latitude and longitude. The results are robust to controlling for these geographic variables. In the remaining columns, I include additional variables and column (6) reports the full specification. Larger cities and more liberal cities pay more for public workers. All else equal, a ten percentage point increase in the Liberal voter registration share is associated with paying local workers $9.2 \%$ more. The Zillow home price elasticity is .22 indicating that cities with higher home prices pay public workers more. What might be important omitted variables? One important one is public sector union effort in contract negotiations. I view this variable to be proxied for by the city's population size and the Liberal share. Such unions are likely to focus their efforts on large Liberal cities. Under the Brueckner and Neumark (2014) hypothesis, the beach coefficient should also reflect such bargaining power but the beach results are not statistically significant. In results that are available on request, I have included interaction terms between the population size, Liberal and beach variables. These interactions are individually and jointly insignificant when I re-run an augmented version of equation (2). 
Table Six reports additional estimates of equations (2) and (3) but I now break out the results by major government categories. The dependent variable is the log of the worker's annual earnings. Column (1) focuses on police, column (2) includes only firemen, and column (3) includes only recreation workers. Across all three job categories, workers in larger cities earn more. In three of the four regressions, the home price index is positively correlated with salaries but its coefficient is low. This suggests that many public sector workers who work in expensive cities either live in smaller homes in that city or commute from lower home price cities in the same county. In all four regressions, I fail to reject the hypothesis that the beach coefficient is zero. Surprisingly, the Liberal variable is no longer positive and statistically significant for these subsamples.

Table Seven reports how California city public worker benefits, overtime and pension attributes vary for city workers within California counties. Beach cities pay lower benefits in nominal terms (not even deflating by real estate prices). Liberal cities pay higher benefits. Neither beach cities nor liberal cities pay more in overtime pay. For $75 \%$ of the sample, I am able to match two attributes of the public sector worker's pension package. These two attributes are the annual defined benefit plan and age of retirement. For example a " $2 \%$ and 60 " worker receives a $2 \%$ of his annual highest salary for each year of service and can retire at age 60 . So a worker whose highest salary is $\$ 90,000$ and who worked for 20 years will receive starting at age 60 an annual payment of $.4 * 90000$ per year. In columns (3) and (4), I run two separate regressions of the "percent amount" and the "minimum age" at retirement. This minimum age, which is often 60 , determines the earliest age such that a worker can begin to receive his defined benefit retirement flow. Perhaps surprisingly, I do not find based on the Zillow variable that higher home price cities feature more generous pensions. I find that beach cities have more 
generous pensions. Beach city workers receive an extra .13 percentage point and they retire at roughly 1 year earlier than other public sector workers in the same county and year.

In Table Eight, I report a new round of estimates of equations (2) and (3) based on employees in public education (grades K-12) in 2015. The data report for all workers in the sector and provide a code for identifying teachers. In Table Eight, I explore the salary and benefits of workers in the K-12 sector. Liberal cities consistently pay more and offer greater benefits but I reject the hypothesis that beach cities pay teachers more.

\section{California City Level Pension Obligations}

There is a growing recognition that many cities have major future liabilities due to defined benefit pension promises made to public sector workers (Novy-Marx and Rauh 2009, Nation 2010). In this section I use California city level data from 2008 to 2013 to study the correlates of a larger per-capital pension obligations (see http://www.pensiontracker.org/). In the Stanford pension tracker data set, two variables reported from 2008 to 2013 are "market liability and "actuarial liability. Market liability is the present value of future benefits for current members, discounted at a market rate of return, ranging from $2.82 \%$ to $4.82 \%$ between 2011 and 2013. The actuarial liability is the present value of future benefits for current members, using discount rates reported by most systems, typically $7.5 \%$.

To study the correlates of a city $\mathrm{i}$ in county $\mathrm{m}$ at time t's pension obligations, I estimate equation (4).

$\log \left(\right.$ Pension Liabilities $\left._{l m t}\right)=\gamma_{m t}+B_{1} *$ Liberal $_{l m t}+B_{2} * \log \left(\right.$ Pop $\left._{l m t}\right)+B_{3} *$ Zillow $_{l m t}+U_{l m t}$ 
The results reported in Table Nine highlight that larger cities and more liberal cities have larger pension obligations. Beach cities do not have higher pension liabilities. The market obligations are much larger than the actuarial liabilities in the more liberal cities.

\section{Conclusion}

The public sector is a major provider of middle class jobs. Both the Federal government and state and local governments employ millions of people. While a large literature has explored the compensating differentials paid across space for private sector workers, we know little about how public sector worker earnings vary with spatial amenities. Compensating differentials theory would predict that they will be inversely related while local union rent extraction theory would posit that they will be positively correlated.

Using a Federal level data set, I have documented that federal workers employed in California are paid only a slight wage premium over observationally identical workers who work in Alabama. This suggests that federal workers are paying a large premium (via high rent prices) to live and work in California.

In contrast to federal workers, there are large differences across space in California city public sector compensation. California features a large public sector that receives a generous defined benefit pension plan. This high amenity state features hundreds of cities that differ with respect to their location and their voters' demographics and political preferences. Access to high quality administrative data provides the opportunity to study the correlates of the public sector's compensation. Using these newly accessible administrative data, I have documented that beach cities hire more public sector workers and do not pay workers higher nominal wages. When I 
deflate local earnings by a median home prices, I find that public sector workers in beach cities earn lower real earnings than public sector workers in non-beach cities who work in the same county in the same year. Workers in liberal cities do earn more than other public sector workers in the same county. This result has implications for such city's aggregate liabilities. 


\section{References}

Alesina A, Baqir R, Easterly W. Redistributive public employment. Journal of Urban Economics. 2000 Sep 30;48(2):219-41.

Blomquist GC, Berger MC, Hoehn JP. New estimates of quality of life in urban areas. The American Economic Review. 1988 Mar 1:89-107.

Brueckner JK, Neumark D. Beaches, sunshine, and public sector pay: theory and evidence on amenities and rent extraction by government workers. American Economic Journal: Economic Policy. 2014 May 1;6(2):198-230.http://www.nber.org/papers/w20692

Diamond, Rebecca. 2017. "Housing Supply Elasticity and Rent Extraction by State and Local Governments." American Economic Journal: Economic Policy, 9(1):74-111

Glaeser EL, Kahn ME. From John Lindsay to Rudy Giuliani: The Decline of the Local Safety Net?. Economic Policy Review. 1999 Sep;5(3).

Gyourko J, Tracy J. The structure of local public finance and the quality of life. Journal of political economy. 1991 Aug 1:774-806.

Gyourko J, Tracy J. An analysis of public and private sector wages allowing for endogenous choices of both government and union status. 1986 NBER Working Paper.

Gyourko J, Mayer C, Sinai T. Superstar cities. American Economic Journal: Economic Policy. 2013 Nov 1;5(4):167-99.

Hwang HS, Reed WR, Hubbard C. Compensating wage differentials and unobserved productivity. Journal of Political Economy. 1992 Aug 1;100(4):835-58.

Kahn ME, Vaughn R, Zasloff J. The housing market effects of discrete land use regulations: Evidence from the California coastal boundary zone. Journal of Housing Economics. 2010 Dec 31;19(4):269-79.

Luttmer EF. Group loyalty and the taste for redistribution. Journal of Political Economy. 2001 Jun;109(3):500-28.

Moretti E. Real wage inequality. American Economic Journal: Applied Economics. 2013 Jan 1;5(1):65-103.

Nation J. The Funding Status of Independent Public Employee Pension Systems in California. Stanford Institute for Economic Policy Research. 2010 Nov.

Novy-Marx R, Rauh JD. The liabilities and risks of state-sponsored pension plans. The Journal of Economic Perspectives. 2009 Nov 1;23(4):191-210. 
Rosen S. Markets and diversity. The American Economic Review. 2002 Mar 1;92(1):1.

Saiz A. The geographic determinants of housing supply. Quarterly Journal of Economics. 2010 Aug 1;125(3).

Storms E, Nation J. More Pension Math: Funded Status, Benefits, and Spending Trends for California's Largest Independent Public Employee Pension Systems. Stanford Institute for Economic Policy Research. 2012 Feb 21.http://publicpay.ca.gov/

Zax JS. Wages, nonwage compensation, and municipal unions. Industrial Relations,. 1988 Sep 1;27(3):301-17. 
Table One

Federal Worker Log Earnings Regressions

\begin{tabular}{|c|c|c|c|c|c|c|}
\hline & 1998 & 2002 & 2006 & 2008 & 2010 & 2014 \\
\hline $\mathrm{AK}$ & $\begin{array}{c}-0.0630 * * * \\
(0.0010)\end{array}$ & $\begin{array}{c}-0.0912 * * * \\
(0.0011)\end{array}$ & $\begin{array}{c}-0.1195 * * * \\
(0.0012)\end{array}$ & $\begin{array}{c}-0.1310 * * * \\
(0.0013)\end{array}$ & $\begin{array}{c}-0.0968 * * * \\
(0.0012)\end{array}$ & $\begin{array}{c}0.0890 * * * \\
(0.0013)\end{array}$ \\
\hline $\mathrm{AZ}$ & $\begin{array}{c}-0.0038 * * * \\
(0.0007)\end{array}$ & $\begin{array}{c}-0.0061 * * * \\
(0.0008)\end{array}$ & $\begin{array}{c}-0.0032 * * * \\
(0.0008)\end{array}$ & $\begin{array}{c}-0.0049 * * * \\
(0.0009)\end{array}$ & $\begin{array}{c}0.0099 * * * \\
(0.0008)\end{array}$ & $\begin{array}{c}0.0067^{* * *} \\
(0.0009)\end{array}$ \\
\hline AR & $\begin{array}{c}-0.0051 * * * \\
(0.0010)\end{array}$ & $\begin{array}{c}-0.0042 * * * \\
(0.0011)\end{array}$ & $\begin{array}{l}-0.0001 \\
(0.0011)\end{array}$ & $\begin{array}{c}-0.0080 * * * \\
(0.0012)\end{array}$ & $\begin{array}{c}0.0012 \\
(0.0011)\end{array}$ & $\begin{array}{c}-0.0069^{* * * *} \\
(0.0012)\end{array}$ \\
\hline $\mathrm{CA}$ & $\begin{array}{c}0.0381 * * * \\
(0.0005)\end{array}$ & $\begin{array}{c}0.0555^{* * *} \\
(0.0006)\end{array}$ & $\begin{array}{c}0.0798 * * * \\
(0.0007)\end{array}$ & $\begin{array}{c}0.0859 * * * \\
(0.0007)\end{array}$ & $\begin{array}{c}0.0988^{* * *} \\
(0.0007)\end{array}$ & $\begin{array}{c}0.0955^{* * * *} \\
(0.0007)\end{array}$ \\
\hline $\mathrm{CO}$ & $\begin{array}{c}0.0102 * * * \\
(0.0007)\end{array}$ & $\begin{array}{c}0.0156^{* * *} \\
(0.0007)\end{array}$ & $\begin{array}{c}0.0313^{* * *} \\
(0.0008)\end{array}$ & $\begin{array}{c}0.0346^{* * *} \\
(0.0009)\end{array}$ & $\begin{array}{c}0.0408^{* * *} \\
(0.0008)\end{array}$ & $\begin{array}{c}0.0318^{* * *} \\
(0.0008)\end{array}$ \\
\hline $\mathrm{CT}$ & $\begin{array}{c}0.0479 * * * \\
(0.0012)\end{array}$ & $\begin{array}{c}0.0579 * * * \\
(0.0013)\end{array}$ & $\begin{array}{c}0.0848 * * * \\
(0.0014)\end{array}$ & $\begin{array}{c}0.0945^{* * *} \\
(0.0015)\end{array}$ & $\begin{array}{c}0.1126^{* * *} \\
(0.0014)\end{array}$ & $\begin{array}{c}0.0963 * * * \\
(0.0014)\end{array}$ \\
\hline $\mathrm{DE}$ & $\begin{array}{c}0.0238^{* * *} \\
(0.0020)\end{array}$ & $\begin{array}{c}0.0233^{* * *} \\
(0.0021)\end{array}$ & $\begin{array}{c}0.0494 * * * \\
(0.0021)\end{array}$ & $\begin{array}{c}0.0531 * * * \\
(0.0023)\end{array}$ & $\begin{array}{c}0.0669^{* * *} \\
(0.0021)\end{array}$ & $\begin{array}{c}0.0604 * * * \\
(0.0021)\end{array}$ \\
\hline DC & $\begin{array}{c}0.0109 * * * \\
(0.0006)\end{array}$ & $\begin{array}{c}0.0135^{* * *} \\
(0.0006)\end{array}$ & $\begin{array}{c}0.0252 * * * \\
(0.0007)\end{array}$ & $\begin{array}{c}0.0387 * * * \\
(0.0007)\end{array}$ & $\begin{array}{c}0.0581 * * * \\
(0.0007)\end{array}$ & $\begin{array}{c}0.0581 * * * \\
(0.0007)\end{array}$ \\
\hline FL & $\begin{array}{c}0.0032 * * * \\
(0.0006)\end{array}$ & $\begin{array}{l}0.0012 * \\
(0.0007)\end{array}$ & $\begin{array}{c}0.0041^{* * *} \\
(0.0007)\end{array}$ & $\begin{array}{c}-0.0036 * * * \\
(0.0008)\end{array}$ & $\begin{array}{c}0.0072 * * * \\
(0.0007)\end{array}$ & $\begin{array}{c}0.0027 * * * \\
(0.0007)\end{array}$ \\
\hline GA & $\begin{array}{c}0.0038 * * * \\
(0.0006)\end{array}$ & $\begin{array}{c}-0.0018 * * * \\
(0.0007)\end{array}$ & $\begin{array}{c}0.0043 * * * \\
(0.0007)\end{array}$ & $\begin{array}{c}0.0039 * * * \\
(0.0008)\end{array}$ & $\begin{array}{c}0.0167 * * * \\
(0.0007)\end{array}$ & $\begin{array}{c}0.0151^{* * * *} \\
(0.0007)\end{array}$ \\
\hline $\mathrm{HI}$ & $\begin{array}{c}-0.0474 * * * \\
(0.0009)\end{array}$ & $\begin{array}{c}-0.0739 * * * \\
(0.0009)\end{array}$ & $\begin{array}{c}-0.0943 * * * \\
(0.0010)\end{array}$ & $\begin{array}{c}-0.1104 * * * \\
(0.0012)\end{array}$ & $\begin{array}{c}-0.0710 * * * \\
(0.0010)\end{array}$ & $\begin{array}{c}0.0448 * * * \\
(0.0010)\end{array}$ \\
\hline ID & $\begin{array}{c}-0.0077 * * * \\
(0.0011)\end{array}$ & $\begin{array}{c}-0.0077 * * * \\
(0.0011)\end{array}$ & $\begin{array}{c}-0.0023^{*} \\
(0.0012)\end{array}$ & $\begin{array}{c}-0.0080 \text { *** } \\
(0.0013)\end{array}$ & $\begin{array}{c}0.0038^{* * *} \\
(0.0013)\end{array}$ & $\begin{array}{c}-0.0052^{* * *} \\
(0.0013)\end{array}$ \\
\hline IL & $\begin{array}{c}0.0234 * * * \\
(0.0007)\end{array}$ & $\begin{array}{c}0.0340^{* * *} \\
(0.0007)\end{array}$ & $\begin{array}{c}0.0453^{* * *} * \\
(0.0008)\end{array}$ & $\begin{array}{c}0.0446 * * * \\
(0.0008)\end{array}$ & $\begin{array}{c}0.0520^{* * *} \\
(0.0008)\end{array}$ & $\begin{array}{c}0.0462 * * * \\
(0.0008)\end{array}$ \\
\hline IN & $\begin{array}{c}-0.0080 * * * \\
(0.0008)\end{array}$ & $\begin{array}{c}0.0005 \\
(0.0009)\end{array}$ & $\begin{array}{c}0.0064^{* * *} \\
(0.0010)\end{array}$ & $\begin{array}{c}-0.0081 * * * \\
(0.0010)\end{array}$ & $\begin{array}{c}0.0003 \\
(0.0010)\end{array}$ & $\begin{array}{c}-0.0060^{* * * *} \\
(0.0010)\end{array}$ \\
\hline IA & $\begin{array}{c}-0.0073 * * * \\
(0.0012)\end{array}$ & $\begin{array}{c}-0.0079 * * * \\
(0.0013)\end{array}$ & $\begin{array}{c}-0.0028^{* *} \\
(0.0013)\end{array}$ & $\begin{array}{c}-0.0092 * * * \\
(0.0014)\end{array}$ & $\begin{array}{c}-0.0042 * * * \\
(0.0014)\end{array}$ & $\begin{array}{c}-0.0089^{* * *} \\
(0.0014)\end{array}$ \\
\hline KS & $\begin{array}{c}-0.0039 * * * \\
(0.0009)\end{array}$ & $\begin{array}{c}-0.0039 * * * \\
(0.0010)\end{array}$ & $\begin{array}{c}-0.0035^{* * *} \\
(0.0010)\end{array}$ & $\begin{array}{c}-0.0155^{* * * *} \\
(0.0011)\end{array}$ & $\begin{array}{c}-0.0091 * * * \\
(0.0010)\end{array}$ & $\begin{array}{c}-0.0119^{* * *} \\
(0.0010)\end{array}$ \\
\hline KY & $\begin{array}{c}0.0073 * * * \\
(0.0009)\end{array}$ & $\begin{array}{l}-0.0010 \\
(0.0009)\end{array}$ & $\begin{array}{c}0.0049 * * * \\
(0.0009)\end{array}$ & $\begin{array}{l}-0.0008 \\
(0.0010)\end{array}$ & $\begin{array}{c}0.0028^{* * *} \\
(0.0009)\end{array}$ & $\begin{array}{c}0.0030^{* * *} \\
(0.0009)\end{array}$ \\
\hline LA & $\begin{array}{c}-0.0036^{* * * *} \\
(0.0008)\end{array}$ & $\begin{array}{l}0.0015^{*} \\
(0.0009)\end{array}$ & $\begin{array}{c}0.0035^{* * *} \\
(0.0010)\end{array}$ & $\begin{array}{c}-0.0082 * * * \\
(0.0010)\end{array}$ & $\begin{array}{l}0.0018^{*} \\
(0.0010)\end{array}$ & $\begin{array}{l}-0.0002 \\
(0.0010)\end{array}$ \\
\hline $\mathrm{ME}$ & $\begin{array}{c}0.0158^{* * *} \\
(0.0012)\end{array}$ & $\begin{array}{c}0.0171 * * * \\
(0.0013)\end{array}$ & $\begin{array}{c}0.0232^{* * *} \\
(0.0013)\end{array}$ & $\begin{array}{c}0.0143 * * * \\
(0.0014)\end{array}$ & $\begin{array}{c}0.0321 * * * \\
(0.0013)\end{array}$ & $\begin{array}{c}0.0235^{* * *} \\
(0.0014)\end{array}$ \\
\hline MD & $\begin{array}{c}0.0164 * * * \\
(0.0006)\end{array}$ & $\begin{array}{c}0.0179 * * * \\
(0.0006)\end{array}$ & $\begin{array}{c}0.0339 * * * \\
(0.0007)\end{array}$ & $\begin{array}{c}0.0484 * * * \\
(0.0007)\end{array}$ & $\begin{array}{c}0.0695 * * * \\
(0.0007)\end{array}$ & $\begin{array}{c}0.0653 * * * \\
(0.0007)\end{array}$ \\
\hline MA & $0.0300^{* * *}$ & $0.0407 * * *$ & $0.0690 * * *$ & $0.0730 * * *$ & $0.0875^{* * *}$ & $0.0817 * * *$ \\
\hline
\end{tabular}




\begin{tabular}{|c|c|c|c|c|c|c|}
\hline & $(0.0008)$ & $(0.0008)$ & $(0.0009)$ & $(0.0009)$ & $(0.0009)$ & $(0.0009)$ \\
\hline MI & $\begin{array}{c}0.0264 * * * \\
(0.0008)\end{array}$ & $\begin{array}{c}0.0340^{* * *} \\
(0.0008)\end{array}$ & $\begin{array}{c}0.0414 * * * \\
(0.0009)\end{array}$ & $\begin{array}{c}0.0384 * * * \\
(0.0009)\end{array}$ & $\begin{array}{c}0.0448^{* * *} \\
(0.0009)\end{array}$ & $\begin{array}{c}0.0329 * * * \\
(0.0009)\end{array}$ \\
\hline $\mathrm{MN}$ & $\begin{array}{c}0.0174 * * * \\
(0.0009)\end{array}$ & $\begin{array}{c}0.0210^{* * *} \\
(0.0010)\end{array}$ & $\begin{array}{c}0.0327^{* * *} \\
(0.0011)\end{array}$ & $\begin{array}{c}0.0292^{* * *} * \\
(0.0011)\end{array}$ & $\begin{array}{c}0.0399 * * * \\
(0.0010)\end{array}$ & $\begin{array}{c}0.0353 * * * \\
(0.0011)\end{array}$ \\
\hline MS & $\begin{array}{c}-0.0103 * * * \\
(0.0009)\end{array}$ & $\begin{array}{c}-0.0066 * * * \\
(0.0009)\end{array}$ & $\begin{array}{c}-0.0034 * * * \\
(0.0010)\end{array}$ & $\begin{array}{c}-0.0071 * * * \\
(0.0011)\end{array}$ & $\begin{array}{c}0.0045^{* * *} \\
(0.0010)\end{array}$ & $\begin{array}{c}-0.0038^{* * *} \\
(0.0010)\end{array}$ \\
\hline MO & $\begin{array}{c}-0.0023 * * * \\
(0.0007)\end{array}$ & $\begin{array}{c}-0.0019^{* *} \\
(0.0008)\end{array}$ & $\begin{array}{c}-0.0004 \\
(0.0008)\end{array}$ & $\begin{array}{c}-0.0095 * * * \\
(0.0009)\end{array}$ & $\begin{array}{c}-0.0047 * * * \\
(0.0008)\end{array}$ & $\begin{array}{c}-0.0107 * * * \\
(0.0008)\end{array}$ \\
\hline MT & $\begin{array}{c}-0.0050 * * * \\
(0.0011)\end{array}$ & $\begin{array}{c}-0.0107 * * * \\
(0.0011)\end{array}$ & $\begin{array}{c}-0.0030 * * * \\
(0.0012)\end{array}$ & $\begin{array}{c}-0.0087 * * * \\
(0.0013)\end{array}$ & $\begin{array}{c}0.0041 * * * \\
(0.0012)\end{array}$ & $\begin{array}{c}-0.0045^{* * *} \\
(0.0013)\end{array}$ \\
\hline $\mathrm{NE}$ & $\begin{array}{c}-0.0068^{* * * *} \\
(0.0011)\end{array}$ & $\begin{array}{c}-0.0117 * * * \\
(0.0012)\end{array}$ & $\begin{array}{c}-0.0050 * * * \\
(0.0012)\end{array}$ & $\begin{array}{c}-0.0150 * * * \\
(0.0014)\end{array}$ & $\begin{array}{c}0.0049 * * * \\
(0.0012)\end{array}$ & $\begin{array}{c}-0.0084 * * * \\
(0.0012)\end{array}$ \\
\hline NV & $\begin{array}{c}-0.0060^{* * * *} \\
(0.0012)\end{array}$ & $\begin{array}{c}-0.0082 * * * \\
(0.0012)\end{array}$ & $\begin{array}{c}-0.0028^{* *} \\
(0.0013)\end{array}$ & $\begin{array}{c}-0.0102 * * * \\
(0.0014)\end{array}$ & $\begin{array}{l}-0.0012 \\
(0.0013)\end{array}$ & $\begin{array}{c}-0.0119 * * * \\
(0.0012)\end{array}$ \\
\hline $\mathrm{NH}$ & $\begin{array}{c}0.0093 * * * \\
(0.0016)\end{array}$ & $\begin{array}{c}0.0186^{* * *} \\
(0.0019)\end{array}$ & $\begin{array}{c}0.0503^{* * *} \\
(0.0020)\end{array}$ & $\begin{array}{c}0.0497 * * * \\
(0.0020)\end{array}$ & $\begin{array}{c}0.0704 * * * \\
(0.0020)\end{array}$ & $\begin{array}{c}0.0599 * * * \\
(0.0019)\end{array}$ \\
\hline NJ & $\begin{array}{c}0.0490^{* * *} \\
(0.0007)\end{array}$ & $\begin{array}{c}0.0636^{* * *} \\
(0.0008)\end{array}$ & $\begin{array}{c}0.0830 * * * \\
(0.0009)\end{array}$ & $\begin{array}{c}0.0937 * * * \\
(0.0009)\end{array}$ & $\begin{array}{c}0.1125 * * * \\
(0.0009)\end{array}$ & $\begin{array}{c}0.1041 * * * \\
(0.0010)\end{array}$ \\
\hline NM & $\begin{array}{c}-0.0025^{* * *} \\
(0.0008)\end{array}$ & $\begin{array}{c}-0.0053 * * * \\
(0.0009)\end{array}$ & $\begin{array}{c}-0.0071 * * * \\
(0.0009)\end{array}$ & $\begin{array}{c}-0.0090 * * * \\
(0.0010)\end{array}$ & $\begin{array}{c}0.0009 \\
(0.0009)\end{array}$ & $\begin{array}{l}-0.0008 \\
(0.0010)\end{array}$ \\
\hline NY & $\begin{array}{c}0.0330^{* * *} \\
(0.0006)\end{array}$ & $\begin{array}{c}0.0406^{* * *} \\
(0.0007)\end{array}$ & $\begin{array}{c}0.0622 * * * \\
(0.0007)\end{array}$ & $\begin{array}{c}0.0635^{* * *} \\
(0.0008)\end{array}$ & $\begin{array}{c}0.0764^{* * *} \\
(0.0007)\end{array}$ & $\begin{array}{c}0.0674 * * * \\
(0.0008)\end{array}$ \\
\hline $\mathrm{NC}$ & $\begin{array}{l}0.0014 * \\
(0.0007)\end{array}$ & $\begin{array}{c}-0.0048 * * * \\
(0.0008)\end{array}$ & $\begin{array}{c}0.0061^{* * *} \\
(0.0008)\end{array}$ & $\begin{array}{c}0.0047^{* * *} \\
(0.0009)\end{array}$ & $\begin{array}{c}0.0116^{* * *} \\
(0.0008)\end{array}$ & $\begin{array}{c}0.0097 * * * \\
(0.0008)\end{array}$ \\
\hline ND & $\begin{array}{c}-0.0077 * * * \\
(0.0014)\end{array}$ & $\begin{array}{c}-0.0076^{* * * *} \\
(0.0015)\end{array}$ & $\begin{array}{c}-0.0057 * * * \\
(0.0015)\end{array}$ & $\begin{array}{c}-0.0109 * * * \\
(0.0016)\end{array}$ & $\begin{array}{c}0.0042 * * * \\
(0.0015)\end{array}$ & $\begin{array}{c}-0.0057^{* * *} \\
(0.0016)\end{array}$ \\
\hline $\mathrm{OH}$ & $\begin{array}{c}0.0094 * * * \\
(0.0007)\end{array}$ & $\begin{array}{c}0.0103 * * * \\
(0.0007)\end{array}$ & $\begin{array}{c}0.0181 * * * \\
(0.0008)\end{array}$ & $\begin{array}{c}0.0103 * * * \\
(0.0008)\end{array}$ & $\begin{array}{c}0.0181 * * * \\
(0.0008)\end{array}$ & $\begin{array}{c}0.0134 * * * \\
(0.0008)\end{array}$ \\
\hline $\mathrm{OK}$ & $\begin{array}{c}-0.0087 * * * \\
(0.0008)\end{array}$ & $\begin{array}{c}-0.0096^{* * * *} \\
(0.0008)\end{array}$ & $\begin{array}{c}-0.0033 * * * \\
(0.0009)\end{array}$ & $\begin{array}{c}-0.0089 * * * \\
(0.0010)\end{array}$ & $\begin{array}{l}-0.0001 \\
(0.0009)\end{array}$ & $\begin{array}{c}-0.0053^{* * *} \\
(0.0009)\end{array}$ \\
\hline OR & $\begin{array}{c}0.0037^{* * *} \\
(0.0008)\end{array}$ & $\begin{array}{c}0.0062^{* * *} \\
(0.0009)\end{array}$ & $\begin{array}{c}0.0202^{* * *} \\
(0.0010)\end{array}$ & $\begin{array}{c}0.0161^{* * *} \\
(0.0010)\end{array}$ & $\begin{array}{c}0.0285^{* * *} \\
(0.0010)\end{array}$ & $\begin{array}{c}0.0190 * * * \\
(0.0010)\end{array}$ \\
\hline PA & $\begin{array}{c}0.0125^{* * *} \\
(0.0006)\end{array}$ & $\begin{array}{c}0.0198^{* * *} \\
(0.0007)\end{array}$ & $\begin{array}{c}0.0357 * * * \\
(0.0007)\end{array}$ & $\begin{array}{c}0.0333 * * * \\
(0.0008)\end{array}$ & $\begin{array}{c}0.0446^{* * *} \\
(0.0007)\end{array}$ & $\begin{array}{c}0.0344 * * * \\
(0.0007)\end{array}$ \\
\hline RI & $\begin{array}{c}0.0010 \\
(0.0013)\end{array}$ & $\begin{array}{c}0.0369 * * * \\
(0.0013)\end{array}$ & $\begin{array}{c}0.0506^{* * *} \\
(0.0019)\end{array}$ & $\begin{array}{c}0.0651^{* * *} \\
(0.0015)\end{array}$ & $\begin{array}{c}0.0777 * * * \\
(0.0018)\end{array}$ & $\begin{array}{c}0.0697 * * * \\
(0.0018)\end{array}$ \\
\hline $\mathrm{SC}$ & $\begin{array}{c}0.0071^{* * *} \\
(0.0009)\end{array}$ & $\begin{array}{c}0.0047 * * * \\
(0.0009)\end{array}$ & $\begin{array}{c}0.0041^{* * *} \\
(0.0010)\end{array}$ & $\begin{array}{c}-0.0048^{* * *} \\
(0.0011)\end{array}$ & $\begin{array}{c}0.0027^{* * *} \\
(0.0010)\end{array}$ & $\begin{array}{c}0.0008 \\
(0.0010)\end{array}$ \\
\hline SD & $\begin{array}{c}-0.0098 * * * \\
(0.0013)\end{array}$ & $\begin{array}{c}-0.0074 * * * \\
(0.0013)\end{array}$ & $\begin{array}{l}-0.0014 \\
(0.0014)\end{array}$ & $\begin{array}{c}-0.0086 * * * \\
(0.0014)\end{array}$ & $\begin{array}{c}0.0010 \\
(0.0014)\end{array}$ & $\begin{array}{c}-0.0052^{* * *} \\
(0.0014)\end{array}$ \\
\hline $\mathrm{TN}$ & $\begin{array}{c}-0.0019 * * \\
(0.0008)\end{array}$ & $\begin{array}{c}-0.0054 * * * \\
(0.0008)\end{array}$ & $\begin{array}{c}0.0022 * * \\
(0.0009)\end{array}$ & $\begin{array}{c}-0.0085^{* * * *} \\
(0.0010)\end{array}$ & $\begin{array}{c}-0.0032 * * * \\
(0.0009)\end{array}$ & $\begin{array}{c}-0.0107 * * * \\
(0.0009)\end{array}$ \\
\hline TX & $\begin{array}{c}0.0047 * * * \\
(0.0006)\end{array}$ & $\begin{array}{c}0.0106 * * * \\
(0.0006)\end{array}$ & $\begin{array}{c}0.0157 * * * \\
(0.0007)\end{array}$ & $\begin{array}{c}0.0168^{* * *} \\
(0.0007)\end{array}$ & $\begin{array}{c}0.0243 * * * \\
(0.0007)\end{array}$ & $\begin{array}{c}0.0247 * * * \\
(0.0007)\end{array}$ \\
\hline UT & $\begin{array}{c}0.0017^{* *} \\
(0.0008)\end{array}$ & $\begin{array}{c}-0.0191^{* * *} \\
(0.0008)\end{array}$ & $\begin{array}{c}-0.0132 * * * \\
(0.0009)\end{array}$ & $\begin{array}{c}-0.0204 * * * \\
(0.0010)\end{array}$ & $\begin{array}{c}-0.0062 * * * \\
(0.0009)\end{array}$ & $\begin{array}{c}-0.0085^{* * *} \\
(0.0009)\end{array}$ \\
\hline VT & $\begin{array}{c}-0.0182 * * * \\
(0.0018)\end{array}$ & $\begin{array}{c}-0.0255^{* * *} \\
(0.0017)\end{array}$ & $\begin{array}{c}-0.0183 * * * \\
(0.0018)\end{array}$ & $\begin{array}{c}-0.0254 * * * \\
(0.0018)\end{array}$ & $\begin{array}{c}-0.0242 * * * \\
(0.0017)\end{array}$ & $\begin{array}{c}-0.0261^{* * *} \\
(0.0020)\end{array}$ \\
\hline VA & $0.0131 * * *$ & $0.0113^{* * *}$ & $0.0173 * * *$ & $0.0225^{* * *}$ & $0.0447 * * *$ & $0.0384 * * *$ \\
\hline
\end{tabular}




\begin{tabular}{|c|c|c|c|c|c|c|}
\hline & $(0.0006)$ & $(0.0006)$ & $(0.0007)$ & $(0.0007)$ & $(0.0007)$ & $(0.0007)$ \\
\hline WA & $\begin{array}{c}0.0102 * * * \\
(0.0007)\end{array}$ & $\begin{array}{c}0.0160 * * * \\
(0.0007)\end{array}$ & $\begin{array}{c}0.0357 * * * \\
(0.0008)\end{array}$ & $\begin{array}{c}0.0357 * * * \\
(0.0008)\end{array}$ & $\begin{array}{c}0.0522 * * * \\
(0.0008)\end{array}$ & $\begin{array}{c}0.0483 * * * \\
(0.0008)\end{array}$ \\
\hline WV & $\begin{array}{c}-0.0126 * * * \\
(0.0010)\end{array}$ & $\begin{array}{c}-0.0112 * * * \\
(0.0010)\end{array}$ & $\begin{array}{c}-0.0028 * * * \\
(0.0011)\end{array}$ & $\begin{array}{c}-0.0024 * * \\
(0.0011)\end{array}$ & $\begin{array}{c}0.0117 * * * \\
(0.0011)\end{array}$ & $\begin{array}{c}0.0063 * * * \\
(0.0011)\end{array}$ \\
\hline WI & $\begin{array}{c}0.0044 * * * \\
(0.0010)\end{array}$ & $\begin{array}{c}0.0067 * * * \\
(0.0011)\end{array}$ & $\begin{array}{c}0.0176^{* * *} \\
(0.0011)\end{array}$ & $\begin{array}{c}0.0089 * * * \\
(0.0012)\end{array}$ & $\begin{array}{c}0.0111^{* * *} \\
(0.0011)\end{array}$ & $\begin{array}{l}-0.0014 \\
(0.0011)\end{array}$ \\
\hline WY & $\begin{array}{c}-0.0134 * * * \\
(0.0014)\end{array}$ & $\begin{array}{c}-0.0174 * * * \\
(0.0014)\end{array}$ & $\begin{array}{c}-0.0074 * * * \\
(0.0015)\end{array}$ & $\begin{array}{c}-0.0123 * * * \\
(0.0017)\end{array}$ & $\begin{array}{c}-0.0037^{* *} \\
(0.0016)\end{array}$ & $\begin{array}{c}-0.0099 * * * \\
(0.0016)\end{array}$ \\
\hline male & $\begin{array}{c}0.0185^{* * *} \\
(0.0002)\end{array}$ & $\begin{array}{c}0.0135^{* * *} \\
(0.0002)\end{array}$ & $\begin{array}{c}0.0035^{* * *} \\
(0.0002)\end{array}$ & $\begin{array}{c}0.0017 * * * \\
(0.0002)\end{array}$ & $\begin{array}{c}-0.0029 * * * \\
(0.0002)\end{array}$ & $\begin{array}{c}-0.0058^{* * * *} \\
(0.0002)\end{array}$ \\
\hline G2 & $\begin{array}{c}0.1364 * * * \\
(0.0019)\end{array}$ & $\begin{array}{c}0.1482 * * * \\
(0.0021)\end{array}$ & $\begin{array}{c}0.1476^{* * *} \\
(0.0024)\end{array}$ & $\begin{array}{c}0.1376^{* * *} \\
(0.0022)\end{array}$ & $\begin{array}{c}0.1220^{* * *} \\
(0.0023)\end{array}$ & $\begin{array}{c}0.1526^{* * *} \\
(0.0039)\end{array}$ \\
\hline G3 & $\begin{array}{c}0.2632 * * * \\
(0.0017)\end{array}$ & $\begin{array}{c}0.2557 * * * \\
(0.0018)\end{array}$ & $\begin{array}{c}0.2685^{* * *} \\
(0.0020)\end{array}$ & $\begin{array}{c}0.2538^{* * *} \\
(0.0018)\end{array}$ & $\begin{array}{c}0.2296 * * * \\
(0.0020)\end{array}$ & $\begin{array}{c}0.2425^{* * *} \\
(0.0034)\end{array}$ \\
\hline G4 & $\begin{array}{c}0.4259^{* * *} \\
(0.0016)\end{array}$ & $\begin{array}{c}0.4159^{* * *} \\
(0.0018)\end{array}$ & $\begin{array}{c}0.4277^{* * *} \\
(0.0019)\end{array}$ & $\begin{array}{c}0.4109 * * * \\
(0.0017)\end{array}$ & $\begin{array}{c}0.3902 * * * \\
(0.0018)\end{array}$ & $\begin{array}{c}0.4037 * * * \\
(0.0032)\end{array}$ \\
\hline G5 & $\begin{array}{c}0.5591 * * * \\
(0.0016)\end{array}$ & $\begin{array}{c}0.5600^{* * *} \\
(0.0018)\end{array}$ & $\begin{array}{c}0.5696^{* * *} \\
(0.0019)\end{array}$ & $\begin{array}{c}0.5433 * * * \\
(0.0017)\end{array}$ & $\begin{array}{c}0.5248 * * * \\
(0.0018)\end{array}$ & $\begin{array}{c}0.5305 * * * \\
(0.0032)\end{array}$ \\
\hline G6 & $\begin{array}{c}0.6786^{* * *} \\
(0.0016)\end{array}$ & $\begin{array}{c}0.6827 * * * \\
(0.0018)\end{array}$ & $\begin{array}{c}0.6899 * * * \\
(0.0019)\end{array}$ & $\begin{array}{c}0.6629 * * * \\
(0.0017)\end{array}$ & $\begin{array}{c}0.6432 * * * \\
(0.0018)\end{array}$ & $\begin{array}{c}0.6519 * * * \\
(0.0032)\end{array}$ \\
\hline G7 & $\begin{array}{c}0.7897 * * * \\
(0.0016)\end{array}$ & $\begin{array}{c}0.7997 * * * \\
(0.0018)\end{array}$ & $\begin{array}{c}0.8048 * * * \\
(0.0019)\end{array}$ & $\begin{array}{c}0.7833 * * * \\
(0.0017)\end{array}$ & $\begin{array}{c}0.7655^{* * *} \\
(0.0018)\end{array}$ & $\begin{array}{c}0.7712 * * * \\
(0.0032)\end{array}$ \\
\hline G8 & $\begin{array}{c}0.9137 * * * \\
(0.0016)\end{array}$ & $\begin{array}{c}0.9282^{* * *} * \\
(0.0018)\end{array}$ & $\begin{array}{c}0.9370 * * * \\
(0.0020)\end{array}$ & $\begin{array}{c}0.9232 * * * \\
(0.0017)\end{array}$ & $\begin{array}{c}0.9075^{* * *} \\
(0.0018)\end{array}$ & $\begin{array}{c}0.9035^{* * *} \\
(0.0032)\end{array}$ \\
\hline G9 & $\begin{array}{c}0.9977 * * * \\
(0.0016)\end{array}$ & $\begin{array}{c}1.0091 * * * \\
(0.0018)\end{array}$ & $\begin{array}{c}1.0188 * * * \\
(0.0019)\end{array}$ & $\begin{array}{c}0.9919 * * * \\
(0.0017)\end{array}$ & $\begin{array}{c}0.9777 * * * \\
(0.0018)\end{array}$ & $\begin{array}{c}0.9882 * * * \\
(0.0032)\end{array}$ \\
\hline G10 & $\begin{array}{c}1.1054 * * * \\
(0.0017)\end{array}$ & $\begin{array}{c}1.1200^{* * * *} \\
(0.0019)\end{array}$ & $\begin{array}{c}1.1407 * * * \\
(0.0021)\end{array}$ & $\begin{array}{c}1.1194 * * * \\
(0.0019)\end{array}$ & $\begin{array}{c}1.1000^{* * * *} \\
(0.0020)\end{array}$ & $\begin{array}{c}1.1052 * * * \\
(0.0033)\end{array}$ \\
\hline G11 & $\begin{array}{c}1.1901^{* * *} \\
(0.0016)\end{array}$ & $\begin{array}{c}1.1987 * * * \\
(0.0018)\end{array}$ & $\begin{array}{c}1.2125^{* * *} \\
(0.0019)\end{array}$ & $\begin{array}{c}1.1852 * * * \\
(0.0017)\end{array}$ & $\begin{array}{c}1.1751^{* * *} \\
(0.0018)\end{array}$ & $\begin{array}{c}1.1819^{* * *} \\
(0.0032)\end{array}$ \\
\hline G12 & $\begin{array}{c}1.3789 * * * \\
(0.0016)\end{array}$ & $\begin{array}{c}1.3871 * * * \\
(0.0018)\end{array}$ & $\begin{array}{c}1.4046^{* * *} \\
(0.0019)\end{array}$ & $\begin{array}{c}1.3766^{* * *} \\
(0.0017)\end{array}$ & $\begin{array}{c}1.3685^{* * *} \\
(0.0018)\end{array}$ & $\begin{array}{c}1.3708^{* * * *} \\
(0.0032)\end{array}$ \\
\hline G13 & $\begin{array}{c}1.5595^{* * *} \\
(0.0016)\end{array}$ & $\begin{array}{c}1.5650 * * * \\
(0.0018)\end{array}$ & $\begin{array}{c}1.5924 * * * \\
(0.0019)\end{array}$ & $\begin{array}{c}1.5641 * * * \\
(0.0017)\end{array}$ & $\begin{array}{c}1.5604 * * * \\
(0.0018)\end{array}$ & $\begin{array}{c}1.5592 * * * \\
(0.0032)\end{array}$ \\
\hline G14 & $\begin{array}{c}1.7388^{* * *} \\
(0.0016)\end{array}$ & $\begin{array}{c}1.7384^{* * *} \\
(0.0018)\end{array}$ & $\begin{array}{c}1.7641 * * * \\
(0.0020)\end{array}$ & $\begin{array}{c}1.7365 * * * \\
(0.0017)\end{array}$ & $\begin{array}{c}1.7457 * * * \\
(0.0018)\end{array}$ & $\begin{array}{c}1.7466^{* * *} \\
(0.0032)\end{array}$ \\
\hline G15 & $\begin{array}{c}1.9171 * * * \\
(0.0017)\end{array}$ & $\begin{array}{c}1.9195^{* * *} \\
(0.0019)\end{array}$ & $\begin{array}{c}1.9448 * * * \\
(0.0020)\end{array}$ & $\begin{array}{c}1.9304 * * * \\
(0.0017)\end{array}$ & $\begin{array}{c}1.9262 * * * \\
(0.0018)\end{array}$ & $\begin{array}{c}1.9255^{* * *} * \\
(0.0032)\end{array}$ \\
\hline Constant & $\begin{array}{c}9.5178^{* * *} \\
(0.0016)\end{array}$ & $\begin{array}{c}9.6737 * * * \\
(0.0019)\end{array}$ & $\begin{array}{c}9.7924 * * * \\
(0.0020)\end{array}$ & $\begin{array}{c}9.8740 * * * \\
(0.0017)\end{array}$ & $\begin{array}{c}9.9221 * * * \\
(0.0019)\end{array}$ & $\begin{array}{c}9.9442 * * * \\
(0.0032)\end{array}$ \\
\hline $\mathrm{N}$ & $1,352,223$ & $1,328,480$ & $1,266,057$ & $1,229,412$ & $1,427,983$ & $1,273,019$ \\
\hline squared & 0.9619 & 0.9584 & 0.9524 & 0.9517 & 0.9488 & 0.9508 \\
\hline
\end{tabular}

Standard errors in parentheses

$* * * \mathrm{p}<0.01, * * \mathrm{p}<0.05, * \mathrm{p}<0.1$

http://publicpay.ca.gov/

Occupational dummies are included in each regression. The omitted category is a Female G1 worker in Alabama. The $\mathrm{G}$ vector represents the 15 grades on the General Schedule. 


\section{Table Two}

California's Beach Cities Included in the Study

\begin{tabular}{|c|c|}
\hline City & County \\
\hline Crescent City & Del Norte \\
\hline Arcata & Humboldt \\
\hline Eureka & Humboldt \\
\hline Ferndale & Humboldt \\
\hline El Segundo & Los Angeles \\
\hline Hermosa Beach & Los Angeles \\
\hline Long Beach & Los Angeles \\
\hline Malibu & Los Angeles \\
\hline Manhattan Beach & Los Angeles \\
\hline Rancho Palos Verdes & Los Angeles \\
\hline Redondo Beach & Los Angeles \\
\hline Santa Monica & Los Angeles \\
\hline Fort Bragg & Mendocino \\
\hline Carmel-By-The-Sea & Monterey \\
\hline Marina & Monterey \\
\hline Monterey & Monterey \\
\hline Pacific Grove & Monterey \\
\hline Salinas & Monterey \\
\hline Sand City & Monterey \\
\hline Seaside & Monterey \\
\hline Dana Point & Orange \\
\hline Huntington Beach & Orange \\
\hline Laguna Beach & Orange \\
\hline Newport Beach & Orange \\
\hline San Clemente & Orange \\
\hline Seal Beach & Orange \\
\hline Carlsbad & San Diego \\
\hline Coronado & San Diego \\
\hline Del Mar & San Diego \\
\hline Encinitas & San Diego \\
\hline Oceanside & San Diego \\
\hline San Diego & San Diego \\
\hline Solana Beach & San Diego \\
\hline Arroyo Grande & San Luis Obispo \\
\hline Grover Beach & San Luis Obispo \\
\hline Morro Bay & San Luis Obispo \\
\hline Pismo Beach & San Luis Obispo \\
\hline San Luis Obispo & San Luis Obispo \\
\hline Daly City & San Mateo \\
\hline Half Moon Bay & San Mateo \\
\hline Pacifica & San Mateo \\
\hline Carpinteria & Santa Barbara \\
\hline Goleta & Santa Barbara \\
\hline Lompoc & Santa Barbara \\
\hline Santa Barbara & Santa Barbara \\
\hline
\end{tabular}


Capitola

Santa Cruz

Oxnard

Port Hueneme
Santa Cruz

Santa Cruz

Ventura

Ventura 


\section{Table Three}

Year 2000 Census Regressions Comparing Beach and Non-Beach Cities

\begin{tabular}{|c|c|c|c|c|c|c|c|c|}
\hline & $(1)$ & (2) & (3) & (4) & $(5)$ & (6) & (7) & $(8)$ \\
\hline & Poverty & Log(Density) & White & Hispanic & College & Income & House Value & Rent \\
\hline \multirow[t]{2}{*}{ Beach City } & -0.0075 & 0.1455 & 0.0324 & $-0.1252 * * *$ & $0.1091 * * *$ & $5,651.1780^{*}$ & $83,942.9118 * *$ & 64.6569 \\
\hline & $(0.0164)$ & $(0.0916)$ & $(0.0382)$ & $(0.0345)$ & $(0.0321)$ & $(3,241.8786)$ & $(32,838.9393)$ & $(45.0237)$ \\
\hline \multirow[t]{2}{*}{ Constant } & $0.1424 * * *$ & $8.6116^{* * *}$ & $0.5928 * * *$ & $0.3527 * * *$ & $0.2578 * * *$ & $50,921.5432 * * *$ & $241,915.3284 * * *$ & $869.7581 * * *$ \\
\hline & $(0.0070)$ & $(0.0494)$ & $(0.0090)$ & $(0.0114)$ & $(0.0072)$ & $(1,034.2512)$ & $(5,400.6446)$ & (10.5016) \\
\hline Observations & 5,678 & 5,678 & 5,678 & 5,678 & 5,678 & 5,661 & 5,585 & 5,652 \\
\hline R-squared & 0.1591 & 0.2519 & 0.1721 & 0.2028 & 0.1964 & 0.1907 & 0.3594 & 0.2912 \\
\hline County & $\mathrm{Y}$ & $\mathrm{Y}$ & $\mathrm{Y}$ & $\mathrm{Y}$ & $\mathrm{Y}$ & $\mathrm{Y}$ & $\mathrm{Y}$ & $\mathrm{Y}$ \\
\hline \multicolumn{9}{|l|}{ Fixed Effect } \\
\hline \multicolumn{9}{|c|}{ Robust standard errors clustered by city reported in parentheses. } \\
\hline \multicolumn{2}{|c|}{$* * * \mathrm{p}<0.01, * * \mathrm{p}<0.05, * \mathrm{p}<0.1$} & & & & & & & \\
\hline
\end{tabular}




\section{Table Four}

Cross-City Variation in California Home Prices and Local Public Employment

\begin{tabular}{|c|c|c|c|c|}
\hline & (1) & (2) & (3) & $(4)$ \\
\hline & Log(Zillow) & Liberal & \multicolumn{2}{|c|}{$\log ($ Count of Workers $)$} \\
\hline & & & Full Time & Part Time \\
\hline \multirow[t]{2}{*}{ Beach City } & $0.4828 * * *$ & -0.0213 & $0.2287^{*}$ & $0.2900 * *$ \\
\hline & $(0.0812)$ & $(0.0149)$ & $(0.1236)$ & $(0.1473)$ \\
\hline \multirow[t]{2}{*}{ City \% Liberal in 2012} & & & $1.0680 * * *$ & 0.4363 \\
\hline & & & $(0.4060)$ & $(0.4797)$ \\
\hline \multirow[t]{2}{*}{ Log of Zillow Home Price } & & & $0.4540 * * *$ & $0.3328 * * *$ \\
\hline & & & $(0.1005)$ & $(0.1210)$ \\
\hline \multirow[t]{2}{*}{ Log of City Population in 2010} & $-0.1054 * * *$ & $0.0199 * * *$ & $0.9764 * * *$ & $0.8279 * * *$ \\
\hline & $(0.0243)$ & $(0.0049)$ & $(0.0348)$ & $(0.0411)$ \\
\hline \multirow[t]{2}{*}{ Constant } & $13.8031 * * *$ & $0.2352 * * *$ & $-10.9226 * * *$ & $-8.6301 * * *$ \\
\hline & $(0.2592)$ & $(0.0510)$ & $(1.5122)$ & $(1.7609)$ \\
\hline Observations & 2,812 & 431 & 2,805 & 2,801 \\
\hline R-squared & 0.7141 & 0.4298 & 0.7957 & 0.6196 \\
\hline County/year Fixed Effects & $\mathrm{Y}$ & $\mathrm{Y}$ & $\mathrm{Y}$ & $\mathrm{Y}$ \\
\hline \multicolumn{5}{|c|}{ Robust standard errors clustered by city reported in parentheses. } \\
\hline$* * * \mathrm{p}<0.01, * * \mathrm{p}<0.05, * \mathrm{p}<0.1$ & & & & \\
\hline
\end{tabular}




\section{Table Five}

\section{California Public Worker Total Salary Regressions}

\begin{tabular}{|c|c|c|c|c|c|c|c|}
\hline & \multicolumn{4}{|c|}{ Log(Total Salary) } & \multicolumn{3}{|c|}{ Log(Total Salary/Zillow Rental) } \\
\hline & $(1)$ & $(2)$ & $(3)$ & (4) & $(5)$ & (6) & $(7)$ \\
\hline \multirow[t]{2}{*}{ Beach City } & 0.0224 & 0.0169 & 0.0259 & -0.0041 & $-0.2701 * * *$ & $-0.2079 * *$ & $-0.1624^{*}$ \\
\hline & $(0.0823)$ & $(0.0817)$ & $(0.0811)$ & $(0.0683)$ & $(0.0960)$ & $(0.0962)$ & $(0.0917)$ \\
\hline \multirow[t]{2}{*}{ Log of City Population in 2010} & $0.2288 * * *$ & $0.2257 * * *$ & $0.2170 * * *$ & $0.2353 * * *$ & $0.2903 * * *$ & $0.2986 * * *$ & $0.2552 * * *$ \\
\hline & $(0.0186)$ & $(0.0196)$ & $(0.0196)$ & $(0.0148)$ & $(0.0159)$ & $(0.0167)$ & $(0.0164)$ \\
\hline \multirow[t]{2}{*}{ Latitude } & & -0.0058 & 0.0214 & 0.1421 & & 0.3374 & $0.4866^{* *}$ \\
\hline & & $(0.2320)$ & $(0.2229)$ & $(0.2111)$ & & $(0.2348)$ & $(0.2169)$ \\
\hline \multirow[t]{2}{*}{ Longitude } & & -0.0963 & -0.0688 & 0.0689 & & $0.3439 * *$ & $0.4831 * * *$ \\
\hline & & $(0.1056)$ & $(0.1031)$ & $(0.1187)$ & & $(0.1497)$ & $(0.1512)$ \\
\hline \multirow[t]{2}{*}{ Log of Zillow Home Price } & & & & $0.2246^{* *}$ & & & \\
\hline & & & & $(0.0896)$ & & & \\
\hline \multirow[t]{2}{*}{ City \% Liberal in 2012} & & & 0.4575 & $0.9186^{* *}$ & & & $2.2691 * * *$ \\
\hline & & & $(0.3278)$ & $(0.3639)$ & & & $(0.3507)$ \\
\hline \multirow[t]{2}{*}{ Constant } & $7.4762 * * *$ & -3.8035 & -1.6074 & 7.2252 & $-3.6347 * * *$ & 25.4200 & $36.1980^{*}$ \\
\hline & $(0.2387)$ & $(14.3236)$ & $(14.1332)$ & $(14.6115)$ & $(0.2057)$ & $(19.2227)$ & $(19.6631)$ \\
\hline Observations & $2,113,843$ & $2,113,843$ & $2,113,384$ & $2,095,945$ & $2,096,404$ & $2,096,404$ & $2,095,945$ \\
\hline R-squared & 0.0831 & 0.0832 & 0.0834 & 0.0858 & 0.1296 & 0.1307 & 0.1379 \\
\hline County/year Fixed Effects & $\mathrm{Y}$ & $\mathrm{Y}$ & $\mathrm{Y}$ & $\mathrm{Y}$ & $\mathrm{Y}$ & $\mathrm{Y}$ & $\mathrm{Y}$ \\
\hline \multicolumn{8}{|c|}{ Robust standard errors clustered by city reported in parentheses. } \\
\hline$* * * \mathrm{p}<0.01, * * \mathrm{p}<0.05, * \mathrm{p}<0.1$ & & & & & & & \\
\hline
\end{tabular}


Table Six

City Public Sector Worker Salary Regressions by Major Sectors

\begin{tabular}{|c|c|c|c|c|c|c|c|}
\hline & \multicolumn{4}{|c|}{ Log(Total Salary) } & \multicolumn{3}{|c|}{ Log(Total Salary/Zillow Rental) } \\
\hline & Police & Police & Fire & Recreation & Police & Fire & Recreation \\
\hline & $(1)$ & $(2)$ & (3) & (4) & $(5)$ & $(6)$ & $(7)$ \\
\hline & & & & & & & \\
\hline \multirow[t]{2}{*}{ Bech City } & 0.0474 & 0.0308 & 0.0465 & $-0.1922^{*}$ & -0.1945 & -0.2144 & $-0.5052 * * *$ \\
\hline & $(0.0377)$ & $(0.0367)$ & $(0.0589)$ & $(0.1107)$ & $(0.1300)$ & $(0.1365)$ & $(0.1204)$ \\
\hline \multirow[t]{2}{*}{ City \% Liberal in 2012} & $-0.4793 * *$ & -0.2937 & $-0.6563 * *$ & 0.0007 & $1.3377 * * *$ & $0.8769^{* *}$ & $2.0670 * * *$ \\
\hline & $(0.1984)$ & $(0.2284)$ & $(0.2599)$ & $(0.4439)$ & $(0.2851)$ & $(0.4321)$ & $(0.6164)$ \\
\hline \multirow[t]{2}{*}{ Log of City Population in 2010} & $0.0479 * * *$ & $0.0492 * * *$ & $0.0490 * * *$ & $0.0962 * * *$ & $0.0560 * * *$ & $0.0934 * * *$ & $0.1230 * *$ \\
\hline & $(0.0083)$ & $(0.0080)$ & $(0.0142)$ & $(0.0228)$ & $(0.0163)$ & $(0.0265)$ & $(0.0503)$ \\
\hline \multirow[t]{2}{*}{ Log of Zillow Home Price } & & $0.0812^{*}$ & & & & & \\
\hline & & $(0.0461)$ & & & & & \\
\hline \multirow[t]{2}{*}{ Constant } & $10.9134 * * *$ & $9.7629 * * *$ & $11.2337 * * *$ & $7.2838 * * *$ & -0.3414 & -0.3109 & $-4.3695 * * *$ \\
\hline & $(0.1002)$ & $(0.6444)$ & $(0.1587)$ & $(0.2562)$ & $(0.2113)$ & $(0.2789)$ & $(0.5341)$ \\
\hline Observations & 293,313 & 291,565 & 113,209 & 128,934 & 291,565 & 112,398 & 128,178 \\
\hline R-squared & 0.0388 & 0.0373 & 0.1701 & 0.0645 & 0.1760 & 0.2771 & 0.1157 \\
\hline \multicolumn{8}{|c|}{ Robust standard errors clustered by city reported in parentheses. } \\
\hline$* * * \mathrm{p}<0.01, * * \mathrm{p}<0.05, * \mathrm{p}<0.1$ & & & & & & & \\
\hline
\end{tabular}




\section{Table Seven}

\section{California Public Sector Worker Benefits and Pension Attributes}

\begin{tabular}{|c|c|c|c|c|}
\hline & (1) & (2) & (3) & (4) \\
\hline & Log(Benefits) & Log(Overtime $)$ & Percent & Retire Age \\
\hline \multirow[t]{2}{*}{ Beach City } & $-0.2607 *$ & -0.0715 & $0.1334^{*}$ & $-0.8843 * * *$ \\
\hline & $(0.1355)$ & $(0.0832)$ & $(0.0761)$ & $(0.2663)$ \\
\hline \multirow[t]{2}{*}{ City \% Liberal in 2012} & $1.3461^{*}$ & 0.3016 & 0.2092 & 1.4208 \\
\hline & $(0.7265)$ & $(0.3946)$ & $(0.2011)$ & $(1.0364)$ \\
\hline \multirow[t]{2}{*}{ Log of Zillow Home Price } & 0.2383 & 0.0048 & $-0.0817^{*}$ & 0.2580 \\
\hline & $(0.1700)$ & $(0.0896)$ & $(0.0467)$ & $(0.2305)$ \\
\hline \multirow[t]{2}{*}{ Log of City Population in 2010} & 0.0077 & $0.1178 * * *$ & $-0.0841 * * *$ & -0.0714 \\
\hline & $(0.0284)$ & $(0.0187)$ & $(0.0139)$ & $(0.0577)$ \\
\hline \multirow[t]{2}{*}{ Constant } & $5.4250 * *$ & $6.4344 * * *$ & $4.4754 * * *$ & $52.5845 * * *$ \\
\hline & $(2.4112)$ & $(1.2720)$ & $(0.6851)$ & $(3.1719)$ \\
\hline Observations & $1,700,845$ & 291,753 & $1,499,913$ & $1,408,252$ \\
\hline R-squared & 0.0787 & 0.0287 & 0.3164 & 0.4372 \\
\hline County Fixed Effects & $\mathrm{Y}$ & $\mathrm{Y}$ & $\mathrm{Y}$ & $\mathrm{Y}$ \\
\hline \multicolumn{5}{|c|}{ Robust standard errors clustered by city reported in parentheses. } \\
\hline$* * * \mathrm{p}<0.01, * * \mathrm{p}<0.05, * \mathrm{p}<0.1$ & & & & \\
\hline
\end{tabular}




\section{Table Eight}

The Determinants of California Public K-12 Education Sector Worker Compensation

\begin{tabular}{|c|c|c|c|c|}
\hline & (1) & (2) & (3) & (4) \\
\hline & All & All & Teachers & Teachers \\
\hline & Log(Salary) & Log(Salary/Zillow) & Log(Salary) & Log(Salary/Zillow) \\
\hline \multirow[t]{2}{*}{ Beach City } & $-0.2684 * * *$ & $-0.4347 * * *$ & -0.1069 & $-0.3170^{*}$ \\
\hline & $(0.0738)$ & $(0.0922)$ & $(0.1699)$ & $(0.1841)$ \\
\hline \multirow[t]{2}{*}{ City \% Liberal in 2012} & $0.8782 * * *$ & $2.6478 * * *$ & $1.3235^{* *}$ & $2.9798 * * *$ \\
\hline & $(0.2464)$ & $(0.3283)$ & $(0.5305)$ & $(0.6227)$ \\
\hline \multirow[t]{2}{*}{ Log of City Population in 2010} & $0.0881 * * *$ & $0.1362 * * *$ & 0.0641 & $0.1338 * *$ \\
\hline & $(0.0209)$ & $(0.0311)$ & $(0.0439)$ & $(0.0554)$ \\
\hline \multirow[t]{2}{*}{ Latitude } & -0.1316 & 0.3579 & $-0.5441 *$ & -0.1155 \\
\hline & $(0.1404)$ & $(0.2369)$ & $(0.2790)$ & $(0.4015)$ \\
\hline \multirow[t]{2}{*}{ Longitude } & -0.0161 & $0.5327 * * *$ & $0.5438 * *$ & $0.9895^{* * *}$ \\
\hline & $(0.0884)$ & $(0.1887)$ & $(0.2399)$ & $(0.3237)$ \\
\hline \multirow[t]{2}{*}{ Constant } & 11.0119 & $47.4918^{* *}$ & $93.0294 * * *$ & $119.1433 * * *$ \\
\hline & $(11.8652)$ & $(23.1687)$ & $(27.8431)$ & $(37.3877)$ \\
\hline Observations & 464,099 & 459,712 & 126,551 & 125,398 \\
\hline R-squared & 0.0184 & 0.0747 & 0.0865 & 0.1396 \\
\hline County Fixed Effects & Y & Y & Y & Y \\
\hline \multicolumn{5}{|c|}{ Robust standard errors clustered by city reported in parentheses. } \\
\hline$* * * \mathrm{p}<0.01, * * \mathrm{p}<0.05, * \mathrm{p}<0.1$ & & & & \\
\hline
\end{tabular}


Table Nine

The Correlates of California City Pension Liabilities

\begin{tabular}{|l|c|c|c|}
\cline { 2 - 4 } & $(1)$ & $(2)$ & $(3)$ \\
\hline & Market & Actuarial & Difference \\
\hline Beach City & & & \\
& 0.2569 & 0.2387 & 0.2017 \\
\hline City \% Liberal in 2012 & $(0.4827)$ & $(0.2255)$ & $(0.3340)$ \\
\hline & $3.8576^{* *}$ & $1.2131 * *$ & $2.6362^{* *}$ \\
\hline Log of Zillow Home Price & $(1.9181)$ & $(0.5900)$ & $(1.3387)$ \\
\hline & 0.0608 & 0.0601 & -0.0166 \\
\hline Log of City Population in 2010 & $(0.4102)$ & $(0.1437)$ & $(0.2907)$ \\
\hline & $0.4695^{* * *}$ & $0.2233 * * *$ & $0.2760 * *$ \\
\hline Constant & $(0.1279)$ & $(0.0443)$ & $(0.0879)$ \\
\hline & -0.0007 & -1.3511 & 1.2808 \\
\hline & $(6.0016)$ & $(2.1240)$ & $(4.2390)$ \\
\hline Observations & & & \\
\hline R-squared & 1,182 & 1,968 & 1,182 \\
\hline County $/ y e a r$ Fixed Effects & 0.3674 & 0.1887 & 0.4301 \\
\hline Robust standard errors clustered by city reported in parentheses. & $\mathrm{Y}$ \\
\hline$* * * \mathrm{p}<0.01, * * \mathrm{p}<0.05, * \mathrm{p}<0.1$ & & & \\
\hline
\end{tabular}

